Article

\title{
Synthesis and Characterization of Bio-Active GFP-P4VP Core-Shell Nanoparticles
}

\author{
Erik Sarnello ${ }^{1}$, Yuzi Liu ${ }^{2}$, Bethany Palen ${ }^{1}$, Elaine Sun ${ }^{3}$, Xiaobing Zuo ${ }^{4}$, Tao $\mathrm{Xu}^{1}{ }^{1}$ and \\ Tao $\mathrm{Li}^{1,4, * \mathbb{D}}$ \\ 1 Department of Chemistry and Biochemistry, Northern Illinois University, Dekalb, IL 60115, USA; \\ Z1837085@students.niu.edu (E.S.); bpalen14@winona.edu (B.P.); txu@niu.edu (T.X.) \\ 2 Center for Nanoscale Materials, Argonne National Laboratory, Lemont, IL 60439, USA; yuziliu@anl.gov \\ 3 Neuqua Valley High School, Naperville, IL 60564, USA; elainesun2624@gmail.com \\ 4 X-ray Science Division, Argonne National Laboratory, Lemont, IL 60439, USA; zuox@anl.gov \\ * Correspondence: taoli@anl.gov or tli4@niu.edu
}

Received: 4 May 2020; Accepted: 3 June 2020; Published: 5 June 2020

check for

\begin{abstract}
Bioactive core-shell nanoparticles (CSNPs) offer the unique ability for protein/enzyme functionality in non-native environments. For many decades, researchers have sought to develop synthetic materials which mimic the efficiency and catalytic power of bioactive macromolecules such as enzymes and proteins. This research studies a self-assembly method in which functionalized, polymer-core/protein-shell nanoparticles are prepared in mild conditions. Transmission electron microscopy (TEM) and dynamic light scattering (DLS) techniques were utilized to analyze the size and distribution of the CSNPs. The methods outlined in this research demonstrate a mild, green chemistry synthesis route for CSNPs which are highly tunable and allow for enzyme/protein functionality in non-native conditions.
\end{abstract}

Keywords: immobilization; assembly; Core-Shell Nanoparticle; protein; polymer

\section{Introduction}

Biomolecules such as proteins and enzymes possess many unique features, the speed and efficiency of which are difficult to match by synthetic materials. Proteins and enzymes are used in a wide variety of applications, including use as a biocatalyst in organic synthesis, as well as in the textile, starch, and detergent industries [1,2]. Unfortunately, many biomolecules lose their stability and functionality outside of their native environment, which limits the scope of their applications. A variety of approaches has been developed to improve their stability while maintaining their functionality [3-5]. One widely used method is to design a core-shell nanoparticle (CSNP) with proteins as its shell [6,7]. Recently, CSNP synthesis methods have been studied through electrostatic and self-assembly [8-10], direct adsorption [11-13], and covalent bonding methods, among others [14,15]. Many studies have focused on the use of proteins in forming CSNPs through direct covalent coupling methods [14-18]. The main drawback with these methods is the fact that covalent bonds are used to adhere the protein/enzyme to the nanoparticle surface. This can often result in protein instability and a loss of biological activity [11,19-24]. The loss of enzyme and protein activity has been noted in electrostatic assembly, direct conjugation, and physical adsorption methods [25-27]. Recent research has outlined an entropically driven assembly process utilizing hydrophobicity effects, similar to Pickering emulsions [23,28-30]. These interactions, along with hydrogen bonding between the polymer-protein, have been shown to result in the formation of stabilized polymer-protein CSNPs without the loss of bioactivity $[23,31]$. 
In this paper, we utilize a co-assembly method to fabricate polymer-green fluorescent protein (GFP) based-CSNPs that can stabilize the GFP structure in non-native conditions without the loss of functionality. The GFP is a 238 amino acid sequence, $26.9 \mathrm{kDa}$ protein, which was discovered in the jellyfish Aequorea Victoria [32,33]. Known for its vibrant fluorescent properties, GFP has applications as a biosensor, physiological indicator, and gene expression tool [34-38]. Poly(4-vinylpyrine) (P4VP) will be the polymer core, because the nitrogen atom in the pyridine group serves as an efficient hydrogen-bonding acceptor [39,40]. P4VP is generally only soluble in organic solvents (e.g., tetrahydrofuran (THF), dimethylformamide (DMF), ethanol), however the assembly occurs in a solution which is roughly a 3:1 volume ratio of aqueous to organic solvent. The formation of the protein-based corona stabilizes the polymer throughout the assembly process and during dialysis in an aqueous solution [23,41,42]. The initial co-assembly process Figure 1) is driven by the highly chemically active surface area of the nanoparticles, which is stabilized by the biomolecules, as well as the hydrogen bonding interactions via the nitrogen atom present in P4VP $[12,22,43,44]$.

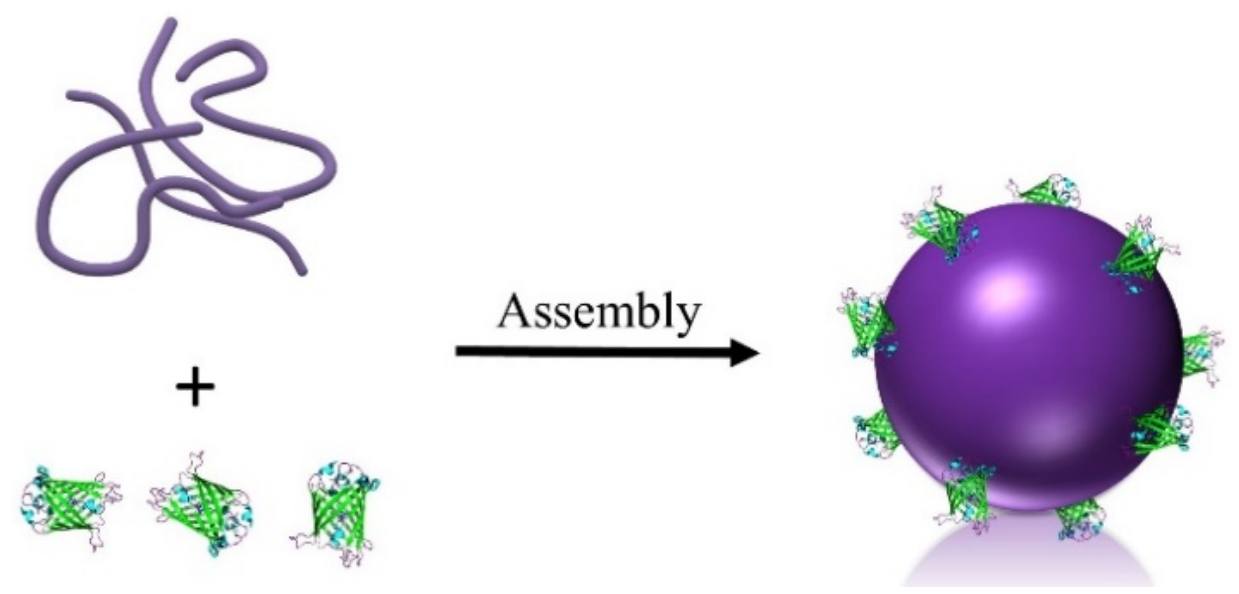

Figure 1. Schematic illustration of the formation of the polymer-protein core-shell nanoparticles (CSNPs).

\section{Results and Discussion}

\subsection{Synthesis and Purification}

During the assembly process, visible changes could be observed within the solution. As P4VP was added, the clear green solution began to become opaque. After thirty minutes, the solution containing the CSNPs underwent dialysis in a buffer solution. After $48 \mathrm{~h}$ of dialysis, the assembly process was completed, and the particles are formed. Past research has used dialysis as a method of removing the organic solvent from the solution [23,30,42]. In this experiment, we employed a $300 \mathrm{kDa}$ molecular weight cut-off dialysis device to allow for any unbonded 26.9 kDa GFP to diffuse out of the reaction mixture, as well as for the removal of the organic solvent. Removal of any excess, unbonded GFP ensures that the only remaining protein in the solution is assembled with the polymer, which is crucial for accurate protein activity testing. Figure 2, a dialysis control test, shows the fluorescence spectra of a GFP solution initially after $24 \mathrm{~h}$ of dialysis, and again after $48 \mathrm{~h}$ of dialysis. The data show that no significant amount of GFP remained in the solution after as little as 24 and $48 \mathrm{~h}$ of dialysis.

\subsection{Size and Surface Characterization}

TEM was employed to characterize the formed assembly structures. A bright field TEM micrograph in Figure 3a shows the P4VP-GFP as smooth, uniformly spherical particles. Although TEM provides useful information about the overall structure of the CSNPs, the surface coverage of the GFP in the CSNPs is another key aspect that needs to be investigated. Past research has reported polymer-protein structures in which the polymer serves as a "chaperone-like" shell wrapped around the protein [45]. 
In order to image the proteins on the nanoparticle surface, $\mathrm{N}$-hydroxysuccinimide (NHS)-activated $15 \mathrm{~nm}$ gold nanoparticles were reacted with the GFP, forming covalently bonded conjugates. The high density of the gold nanoparticles provides a much higher contrast in TEM imaging [46,47]. Since they are covalently bonded to the GFP, it will allow the indirect visualization of the GFP in the CSNPs. The gold-GFP particles were then assembled with P4VP before being analyzed via TEM. Figure $3 \mathrm{~b}$ shows a TEM image in which the gold nanoparticles are uniformly distributed on the surface of the polymer core, indicating that the GFP has good surface coverage on the P4VP sphere. To test whether the GFP is completely on the surface of the P4VP sphere or partially inside the sphere, TEM electron tomography (ET) was used to image the CSNPs. TEM ET utilizes a series of tilted TEM images that can be reconstructed to reveal a three-dimensional object [48,49]. A series of ET images of a P4VP + GFP-gold conjugate particle at different tilted angles are displayed in Figure $3 c-h$. It is worth noting that the dark circular region present in Figure $3 c-h$ is the result of free P4VP + GFP-gold conjugate particles in the solution that settled at the CSNP-TEM grid interface during TEM sample preparation.

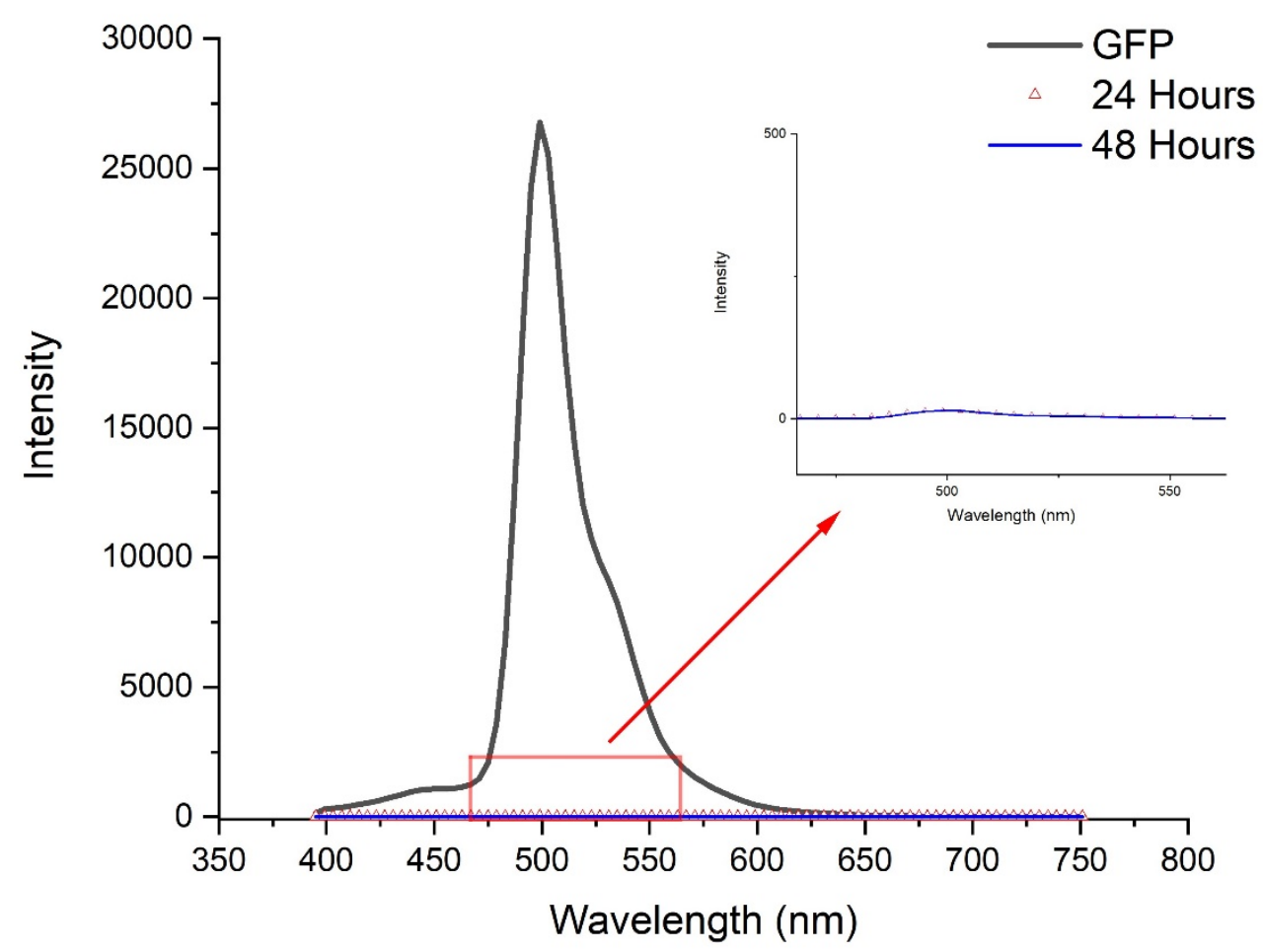

Figure 2. Fluorescence spectra of the dialysis control test. The spectra show no significant amount of green fluorescent protein (GFP) remaining after $24 \mathrm{~h}$.

Another key aspect of these polymer-protein CSNPs is the ability to control their relative size distribution. By adjusting the polymer-protein reaction ratio, varying unimodal size distributions can be synthesized. Figure 4 shows the TEM images of reactions G1, G2, and G3. As the polymer to protein ratio was increased, the data show that the average particle size increased as well. For each reaction, the concentration of reagents was set constant. The varying polymer-GFP ratios of 0.25 , 0.60 , and 1.0 were calculated by changing the total volume of the P4VP solution added to the mixture. As the P4VP-GFP ratios increased from 0.25 to 1.0 (Figure $4 \mathrm{a}-\mathrm{c}$ ), the particle size obtained from TEM became larger. Without the presence of the GFP, the P4VP precipitates out from the solution (data not shown). Although traditional TEM is a valuable tool for the characterization of nanoparticles, sample preparation requires samples to be dried out, which is not ideal for the characterization of colloidal systems. 


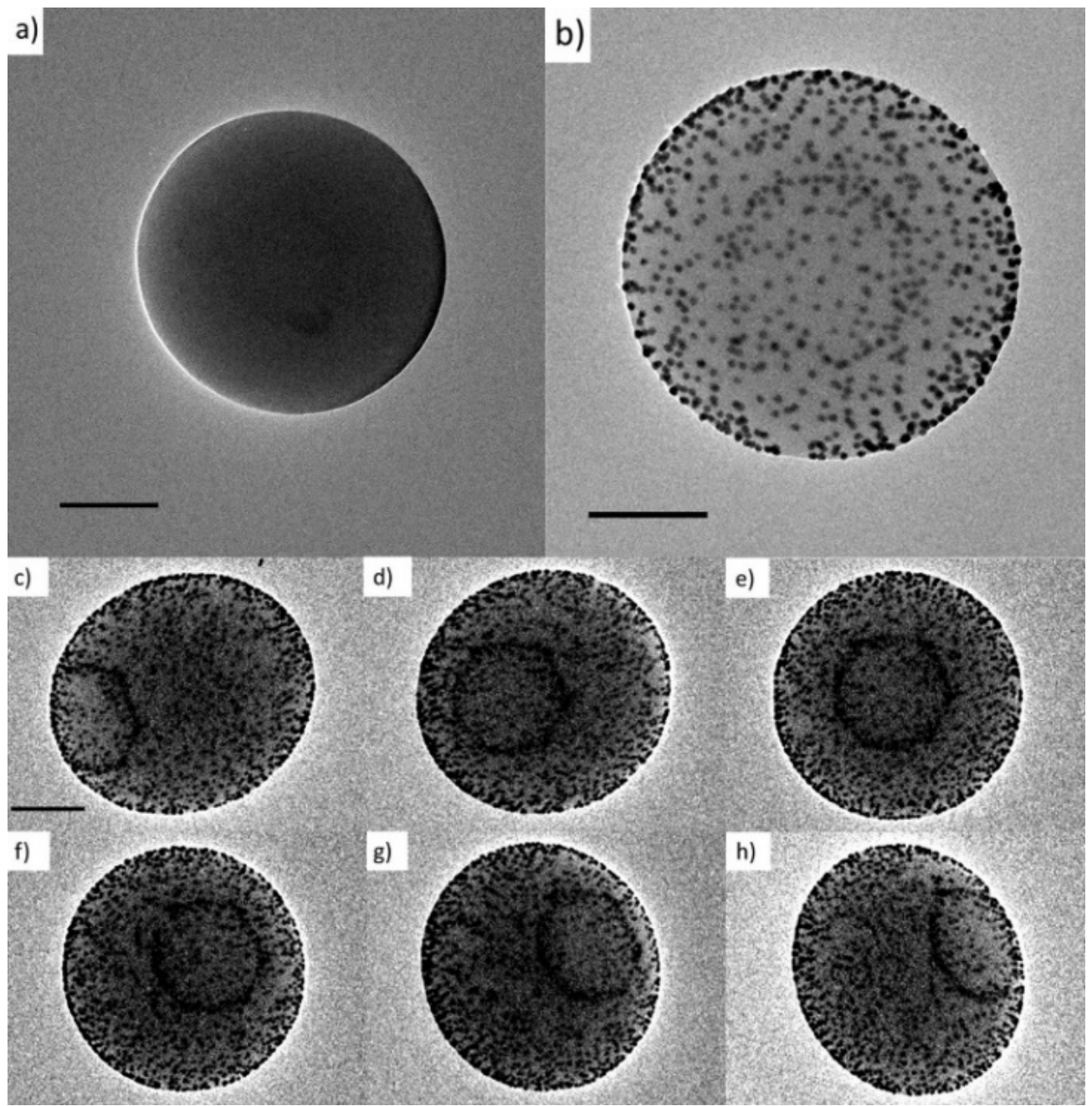

Figure 3. (a) Transmission electron microscopy (TEM) image of Poly(4-vinylpyrine) (P4VP) + GFP CSNP. (b) TEM image of P4VP + GFP-gold conjugated particles. The high contrast of the gold nanoparticles shows the distribution of GFP on the surface of the particle. (c-h) TEM tomography images as the $\mathrm{P} 4 \mathrm{VP}+\mathrm{GFP}-$ gold conjugated particle is rotated. All scale bars are $200 \mathrm{~nm}$.

To analyze the samples in the solution state, dynamic light scattering (DLS) was used to statistically determine the average particle size and size distribution of each of the CSNP samples, as seen in Figure 4d. Analysis of the DLS size distribution data showed distinct unimodal peaks for each sample. The data also showed the direct effect that the polymer-protein ratio had on the overall particle size, i.e., the average particle size increased as the P4VP concentration increased, similar to what was observed from the TEM results. Reactions G1, G2, and G3 generated average particles sizes of roughly 500, 750, and $900 \mathrm{~nm}$, respectively. Once the size distribution of the CSNPs was determined, it was important to determine if the GFP on the surface of the P4VP was present/active. The fluorescence profile of the GFP and the various CSNPs can be seen in Figure 5. The data are consistent with known values, corresponding to an emission spectrum that contains $\lambda_{\max }$ around $509 \mathrm{~nm}$ followed by a shoulder peak at $545 \mathrm{~nm}$ [50]. The smaller peak around $425 \mathrm{~nm}$ present in the spectra of the CSNPs is characteristic of the P4VP fluorescence profile, as seen in Figure 5. The presence of fluorescence suggests the GFP still remains in its native structure, since unfolding leads to the loss of fluorescence [51]. 

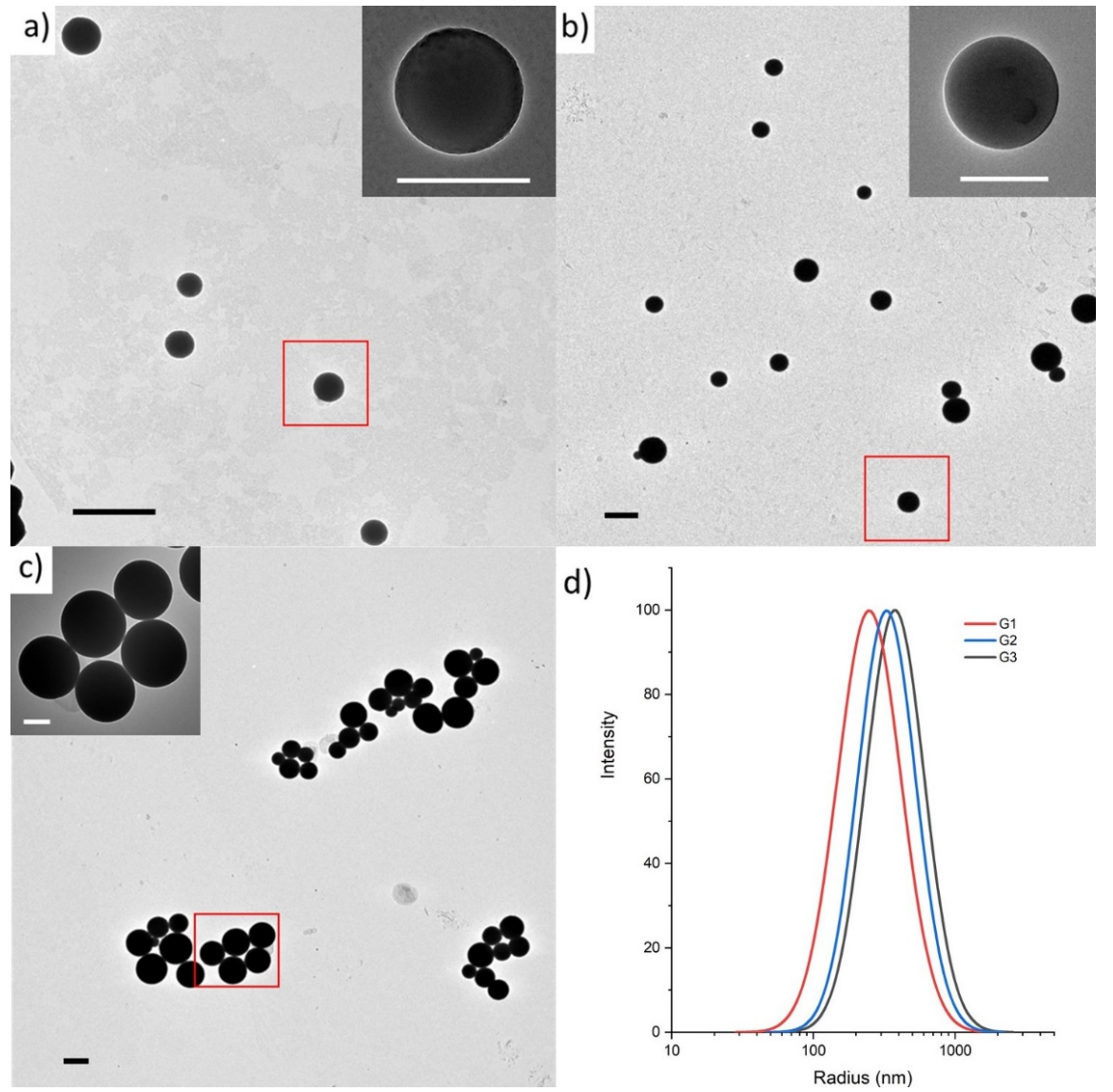

Figure 4. (a-c) TEM images of CSNPs from reactions (a) G1, (b) G2, and (c) G3. (d) Size distribution of CSNPs determined via DLS. Scale bars for low magnification images for $a, b$, and $c$ are $1 \mu \mathrm{m}$. Scale bars for red box images for $a, b$, and $c$ are $0.5 \mu \mathrm{m}$.

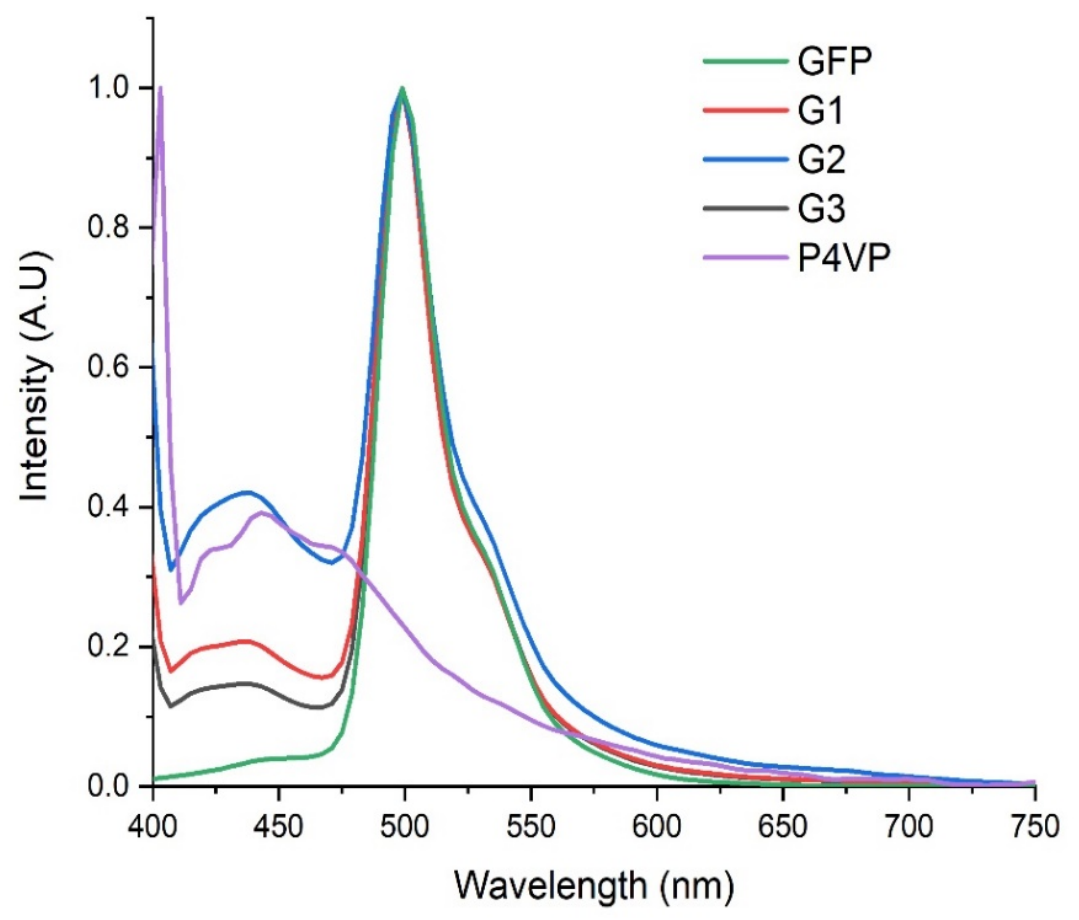

Figure 5. Fluorescence spectra of GFP, P4VP, and CSNPs with various sizes. 


\section{Experimental Section}

\subsection{Chemicals and Materials}

Poly(4-vinylpyridine) (P4VP; Mw 60,000) and N,N-Dimethylformamide (DMF; anhydrous, 99.8\%) were purchased from Sigma-Aldrich (St. Louis, MO, USA). 4-(2-hydroxyethyl)-1piperazineethanesulfonic acid (HEPES; 99\%) was purchased from Acros Organics (Fair Lawn, NJ, USA). Sodium chloride was purchased from Fisher Scientific (Hamptons, NH, USA). Sodium hydroxide pellets were purchased from the Ricca Chemical Company (Arlington, TX, USA). The GFP was prepared $(4 \mathrm{mg} / \mathrm{mL}$ ) in a $20 \mathrm{mM}$ tris(hydroxymethyl)aminomethane (Tris) $\mathrm{pH} 7.0,80 \mathrm{mM} \mathrm{NaCl}$, and $2 \mathrm{mM}$ EDTA buffer solution. All reagents were used as received. All water used in this experiment was of ultrapure type I purity $(18.2 \mathrm{M} \Omega \cdot \mathrm{cm})$ obtained via an Elga Purelab Flex2 system. Float-A-Lyzer ${ }^{\circledR} \mathrm{G} 2$ dialysis devices $(300 \mathrm{kDa})$ used for dialysis were purchased from Spectrum Labs (Cincinnati, OH, USA). All dialysis devices were pre-treated via a $10 \%$ ethanol bath for ten minutes before being thoroughly rinsed in $\mathrm{DI} \mathrm{H}_{2} \mathrm{O}$, as per manufacturer's instructions. The $15 \mathrm{~nm}$ NHS-activated gold nanoparticles were purchased from Cytodiagnostics Inc (Burlington, Canada).

\subsection{Sample Preparation}

The preparation methods for the GFP have been published [52]. The synthesis of the CSNPs was as follows: For sample G1, a solution containing P4VP (Mw $60 \mathrm{kDa})$ in DMF $(2.0 \mathrm{mg} / \mathrm{mL}, 0.05 \mathrm{~mL})$ was added dropwise, in $40 \mu \mathrm{L}$ increments, to a $3.7 \mathrm{~mL}$ glass vial containing the GFP $(0.8 \mathrm{mg} / \mathrm{mL}, 0.5 \mathrm{~mL})$ in a $20 \mathrm{mM}$ tris(hydroxymethyl)aminomethane (Tris) pH 7.0, $80 \mathrm{mM} \mathrm{NaCl}$, and $2 \mathrm{mM}$ EDTA buffer solution. The solution was constantly stirred during the addition of the P4VP. The vial was then sealed for thirty minutes before undergoing dialysis. Dialysis was done in a 1.0 L $10 \mathrm{mM}$ HEPES and $250 \mathrm{mM}$ $\mathrm{NaCl}$ solution. The dialysis solution was replaced by a fresh solution after $4,6,10$, and $12 \mathrm{~h}$. Once dialysis was complete, the solution containing the CSNPs was then retrieved from the dialysis tube using a pipette. All samples in this research were synthesized using the above procedure, with only variations in the amount of P4VP that was added. P4VP volumes of 0.12 and $0.20 \mathrm{~mL}$ were used for G2 and G3, respectively.

\subsection{Characterization}

Dynamic light scattering (DLS) and zeta potential measurements were performed using a Nanobrook Omni particle size and zeta potential analyzer by Brookhaven Instruments. Typically, $100 \mu \mathrm{L}$ of concentrated sample was diluted to $2 \mathrm{~mL}$ and loaded into a polystyrene cuvette. The samples underwent a five-minute equilibration time before undergoing five five-minute scans. All data were collected at a $90^{\circ}$ scattering angle.

Transmission electron microscopy (TEM) was performed using a JEOL JEM2100F field emission transmission electron microscope. The samples were prepared on 400 mesh carbon-coated copper grids by submerging the grids in $100 \mu \mathrm{L}$ droplets containing a 50:50 mixture of sample and ultra-pure water. The grids were allowed to soak for twenty minutes before being transferred to a $100 \mu \mathrm{L}$ droplet of ultra-pure water to rinse. The rinsing process was repeated an additional time before being allowed to dry.

The fluorescence profiles were measured using a NanoDrop ${ }^{\mathrm{TM}} 3300$ fluorospectrometer (ThermoFisher Scientific). For fluorescence measurements, the samples were placed directly, in $2 \mu \mathrm{L}$ aliquots, onto the microvolume pedestal. No sample preparation was required.

\subsection{Gold-GFP Conjugation}

Covalent conjugation of the gold-GFP particles was performed in accordance with the manufacturer's instructions. In short, all reagents were allowed to warm up to room temperature before the supplied protein re-suspension buffer was added to the lyophilized GFP to create a $2 \mathrm{mg} / \mathrm{mL}$ solution. In a microcentrifuge tube, the supplied reaction buffer $(600 \mu \mathrm{L})$ was combined with the 
GFP solution $(480 \mu \mathrm{L})$. An amount of $900 \mu \mathrm{L}$ of the new mixture was then transferred to a glass vial containing the lyophilized NHS-activated gold nanoparticles. The resulting solution was mixed thoroughly using a pipette. The vial was then allowed to incubate at room temperature for two hours before the supplied quencher solution $(10 \mu \mathrm{L})$ was added to the vial to stop the reaction. The solution was then centrifuged at 15,000 RPM for $30 \mathrm{~min}$. The supernatant containing any unbound protein was then discarded. An amount of $1 \mathrm{~mL}$ of a $10 \mathrm{mM}$ HEPES and $250 \mathrm{mM} \mathrm{NaCl}$ buffer was added to the vial to re-suspend the conjugate. The centrifugation process was then repeated two additional times to remove any unreacted free protein.

\section{Conclusions}

This research outlines a direct, stepwise assembly process for the synthesis of bio-active GFP-P4VP CSNPs. GFP has been shown to be present and stable on the surface of the polymer nanoparticles. The non-covalent bonding interaction provides a secure, non-hindering interaction between the GFP and the polymer. We have shown that the size range of the CSNPs can be easily controlled by adjusting the polymer-protein ratio as confirmed by the DLS and TEM images [53]. This procedure demonstrates a method for the stabilization of bio-active molecules via polymer-core CSNPs. These particles will allow for a variety of applications, from industrial to biomedical, to utilize the power and efficiency of bio-active molecules outside of their native environment.

Author Contributions: The manuscript was written through contributions of all authors. All authors contributed equally. All authors have read and agreed to the published version of the manuscript.

Funding: This research was funded by U.S. DOE, grant number DE-AC02-06CH11357.

Acknowledgments: The authors are thankful for the use of the Advanced Photon Source, Center for Nanoscale Materials an Office of Science User Facility operated for the U.S. Department of Energy (DOE), Office of Science by Argonne National Laboratory was supported by the U.S. DOE under Contract No. DE-AC02-06CH11357. T.L. is thankful for startup support from Northern Illinois University.

Conflicts of Interest: The authors declare no competing financial interest.

\section{References}

1. Li, S.; Yang, X.; Yang, S.; Zhu, M.; Wang, X. Technology Prospecting on Enzymes: Application, Marketing And Engineering. Comput. Struct. Biotechnol. J. 2012, 2, e201209017. [CrossRef] [PubMed]

2. Kirk, O.; Borchert, T.V.; Fuglsang, C.C. Industrial enzyme applications. Curr. Opin. Biotechnol. 2002, 13, 345-351. [CrossRef]

3. Morgenstern, J.; Gil Alvaradejo, G.; Bluthardt, N.; Beloqui, A.; Delaittre, G.; Hubbuch, J. Impact of Polymer Bioconjugation on Protein Stability and Activity Investigated with Discrete Conjugates: Alternatives to PEGylation. Biomacromolecules 2018, 19, 4250-4262. [CrossRef] [PubMed]

4. Wan, L.; Chen, Q.; Liu, J.; Yang, X.; Huang, J.; Li, L.; Guo, X.; Zhang, J.; Wang, K. Programmable Self-Assembly of DNA-Protein Hybrid Hydrogel for Enzyme Encapsulation with Enhanced Biological Stability. Biomacromolecules 2016, 17, 1543-1550. [CrossRef] [PubMed]

5. Murata, H.; Cummings, C.S.; Koepsel, R.R.; Russell, A.J. Polymer-Based Protein Engineering Can Rationally Tune Enzyme Activity, pH-Dependence, and Stability. Biomacromolecules 2013, 14, 1919-1926. [CrossRef]

6. Hoener, C.F.; Allan, K.A.; Bard, A.J.; Campion, A.; Fox, M.A.; Mallouk, T.E.; Webber, S.E.; White, J.M. Demonstration of a shell-core structure in layered cadmium selenide-zinc selenide small particles by $\mathrm{x}$-ray photoelectron and Auger spectroscopies. J. Phys. Chem. 1992, 96, 3812-3817. [CrossRef]

7. Ghosh Chaudhuri, R.; Paria, S. Core/Shell Nanoparticles: Classes, Properties, Synthesis Mechanisms, Characterization, and Applications. Chem. Rev. 2012, 112, 2373-2433. [CrossRef] [PubMed]

8. Liu, Y.; Wu, H.-C.; Chhuan, M.; Terrell, J.L.; Tsao, C.-Y.; Bentley, W.E.; Payne, G.F. Functionalizing Soft Matter for Molecular Communication. Acs Biomater. Sci. Eng. 2015, 1, 320-328. [CrossRef]

9. Chen, X.; Gerasopoulos, K.; Guo, J.; Brown, A.; Wang, C.; Ghodssi, R.; Culver, J.N. Virus-Enabled Silicon Anode for Lithium-Ion Batteries. Acs Nano 2010, 4, 5366-5372. [CrossRef] [PubMed] 
10. Gallat, F.-X.; Brogan, A.P.S.; Fichou, Y.; McGrath, N.; Moulin, M.; Härtlein, M.; Combet, J.; Wuttke, J.; Mann, S.; Zaccai, G.; et al. A Polymer Surfactant Corona Dynamically Replaces Water in Solvent-Free Protein Liquids and Ensures Macromolecular Flexibility and Activity. J. Am. Chem. Soc. 2012, 134, 13168-13171. [CrossRef] [PubMed]

11. Gebauer, J.S.; Malissek, M.; Simon, S.; Knauer, S.K.; Maskos, M.; Stauber, R.H.; Peukert, W.; Treuel, L. Impact of the Nanoparticle-Protein Corona on Colloidal Stability and Protein Structure. Langmuir 2012, 28, 9673-9679. [CrossRef] [PubMed]

12. Klein, J. Probing the interactions of proteins and nanoparticles. Proc. Natl. Acad. Sci. USA 2007, 104, 2029-2030. [CrossRef] [PubMed]

13. Mahmoudi, M.; Lynch, I.; Ejtehadi, M.R.; Monopoli, M.P.; Bombelli, F.B.; Laurent, S. Protein-Nanoparticle Interactions: Opportunities and Challenges. Chem. Rev. 2011, 111, 5610-5637. [CrossRef] [PubMed]

14. Tao, L.; Mantovani, G.; Lecolley, F.; Haddleton, D.M. $\alpha$-Aldehyde Terminally Functional Methacrylic Polymers from Living Radical Polymerization: Application in Protein Conjugation "Pegylation". J. Am. Chem. Soc. 2004, 126, 13220-13221. [CrossRef] [PubMed]

15. Bartczak, D.; Kanaras, A.G. Preparation of Peptide-Functionalized Gold Nanoparticles Using One Pot EDC/Sulfo-NHS Coupling. Langmuir 2011, 27, 10119-10123. [CrossRef] [PubMed]

16. Liu, E.Y.; Jung, S.; Yi, H. Improved Protein Conjugation with Uniform, Macroporous Poly(acrylamide-co-acrylic acid) Hydrogel Microspheres via EDC/NHS Chemistry. Langmuir 2016, 32, 11043-11054. [CrossRef]

17. Totaro, K.A.; Liao, X.; Bhattacharya, K.; Finneman, J.I.; Sperry, J.B.; Massa, M.A.; Thorn, J.; Ho, S.V.; Pentelute, B.L. Systematic Investigation of EDC/sNHS-Mediated Bioconjugation Reactions for Carboxylated Peptide Substrates. Bioconjugate Chem. 2016, 27, 994-1004. [CrossRef]

18. Heredia, K.L.; Bontempo, D.; Ly, T.; Byers, J.T.; Halstenberg, S.; Maynard, H.D. In Situ Preparation of Protein-“Smart" Polymer Conjugates with Retention of Bioactivity. J. Am. Chem. Soc. 2005, 127, 16955-16960. [CrossRef]

19. Vertegel, A.A.; Siegel, R.W.; Dordick, J.S. Silica Nanoparticle Size Influences the Structure and Enzymatic Activity of Adsorbed Lysozyme. Langmuir 2004, 20, 6800-6807. [CrossRef]

20. Kittler, S.; Greulich, C.; Gebauer, J.S.; Diendorf, J.; Treuel, L.; Ruiz, L.; Gonzalez-Calbet, J.M.; Vallet-Regi, M.; Zellner, R.; Köller, M.; et al. The influence of proteins on the dispersability and cell-biological activity of silver nanoparticles. J. Mater. Chem. 2010, 20, 512-518. [CrossRef]

21. Lynch, I.; Salvati, A.; Dawson, K.A. What does the cell see? Nat. Nanotechnol. 2009, 4, 546-547. [CrossRef] [PubMed]

22. Monopoli, M.P.; Walczyk, D.; Campbell, A.; Elia, G.; Lynch, I.; Baldelli Bombelli, F.; Dawson, K.A. Physical-Chemical Aspects of Protein Corona: Relevance to in Vitro and in Vivo Biological Impacts of Nanoparticles. J. Am. Chem. Soc. 2011, 133, 2525-2534. [CrossRef] [PubMed]

23. Suthiwangcharoen, N.; Li, T.; Wu, L.; Reno, H.B.; Thompson, P.; Wang, Q. Facile Co-Assembly Process to Generate Core-Shell Nanoparticles with Functional Protein Corona. Biomacromolecules 2014, 15, 948-956. [CrossRef] [PubMed]

24. Shu, J.Y.; Huang, Y.-J.; Tan, C.; Presley, A.D.; Chang, J.; Xu, T. Amphiphilic Peptide-Polymer Conjugates Based on the Coiled-Coil Helix Bundle. Biomacromolecules 2010, 11, 1443-1452. [CrossRef] [PubMed]

25. Parajuli, O.; Gupta, A.; Kumar, N.; Hahm, J.-i. Evaluation of Enzymatic Activity on Nanoscale Polystyrene-block-Polymethylmethacrylate Diblock Copolymer Domains. J. Phys. Chem. B 2007, 111, 14022-14027. [CrossRef] [PubMed]

26. Sharma, K.P.; Collins, A.M.; Perriman, A.W.; Mann, S. Enzymatically Active Self-Standing Protein-Polymer Surfactant Films Prepared by Hierarchical Self-Assembly. Adv. Mater. 2013, 25, 2005-2010. [CrossRef]

27. Ventura, J.; Eron, S.J.; González-Toro, D.C.; Raghupathi, K.; Wang, F.; Hardy, J.A.; Thayumanavan, S. Reactive Self-Assembly of Polymers and Proteins to Reversibly Silence a Killer Protein. Biomacromolecules 2015, 16, 3161-3171. [CrossRef] [PubMed]

28. Russell, J.T.; Lin, Y.; Böker, A.; Su, L.; Carl, P.; Zettl, H.; He, J.; Sill, K.; Tangirala, R.; Emrick, T.; et al. Self-Assembly and Cross-Linking of Bionanoparticles at Liquid-Liquid Interfaces. Angew. Chem. Int. Ed. 2005, 44, 2420-2426. [CrossRef] 
29. Rijn, P.; C Mougin, N.; Franke, D.; Park, H.; Böker, A. Pickering emulsion templated soft capsules by self-assembling cross-linkable ferritin-polymer conjugates. Chem. Commun. 2011, 47, 8376-8378. [CrossRef] [PubMed]

30. Li, T.; Wu, L.; Suthiwangcharoen, N.; Bruckman, M.A.; Cash, D.; Hudson, J.S.; Ghoshroy, S.; Wang, Q. Controlled assembly of rodlike viruses with polymers. Chem. Commun. 2009, 20, 2869-2871. [CrossRef]

31. Zhang, X.; Zhao, X.; Luckanagul, J.A.; Yan, J.; Nie, Y.; Lee, L.A.; Wang, Q. Polymer-Protein Core-Shell Nanoparticles for Enhanced Antigen Immunogenicity. Acs Macro Lett. 2017, 6, 442-446. [CrossRef]

32. Prendergast, F.G.; Mann, K.G. Chemical and physical properties of aequorin and the green fluorescent protein isolated from Aequorea forskalea. Biochemistry 1978, 17, 3448-3453. [CrossRef] [PubMed]

33. Shimomura, O.; Johnson Frank, H.; Saiga, Y. Extraction, Purification and Properties of Aequorin, a Bioluminescent Protein from the Luminous Hydromedusan, Aequorea. J. Cell. Comp. Physiol. 1962, 59, 223-239. [CrossRef] [PubMed]

34. Kneen, M.; Farinas, J.; Li, Y.; Verkman, A.S. Green fluorescent protein as a noninvasive intracellular $\mathrm{pH}$ indicator. Biophys. J. 1998, 74, 1591-1599. [CrossRef]

35. Tsien, R.Y. The Green Fluorescent Protein. Annu. Rev. Biochem. 1998, 67, 509-544. [CrossRef] [PubMed]

36. Cody, C.W.; Prasher, D.C.; Westler, W.M.; Prendergast, F.G.; Ward, W.W. Chemical structure of the hexapeptide chromophore of the Aequorea green-fluorescent protein. Biochemistry 1993, 32, 1212-1218. [CrossRef] [PubMed]

37. Chalfie, M.; Tu, Y.; Euskirchen, G.; Ward, W.W.; Prasher, D.C. Green fluorescent protein as a marker for gene expression. Science 1994, 263, 802-805. [CrossRef] [PubMed]

38. Heim, R.; Prasher, D.C.; Tsien, R.Y. Wavelength mutations and posttranslational autoxidation of green fluorescent protein. Proc. Natl. Acad. Sci. USA 1994, 91, 12501-12504. [CrossRef]

39. Tamres, M.; Searles, S.; Leighly, E.M.; Mohrman, D.W. Hydrogen Bond Formation with Pyridines and Aliphatic Amines1. J. Am. Chem. Soc. 1954, 76, 3983-3985. [CrossRef]

40. Li, T.; Zhou, P.; Mattei, A. Electronic origin of pyridinyl $\mathrm{N}$ as a better hydrogen-bonding acceptor than carbonyl O. CrystEngComm 2011, 13, 6356-6360. [CrossRef]

41. Vyhnalkova, R.; Müller, A.H.E.; Eisenberg, A. Control of Morphology and Corona Composition in Aggregates of Mixtures of PS-b-PAA and PS-b-P4VP Diblock Copolymers: Effects of Solvent, Water Content, and Mixture Composition. Langmuir 2014, 30, 13152-13163. [CrossRef] [PubMed]

42. Li, T.; Niu, Z.; Emrick, T.; Russell, T.P.; Wang, Q. Core/Shell Biocomposites from the Hierarchical Assembly of Bionanoparticles and Polymer. Small 2008, 4, 1624-1629. [CrossRef] [PubMed]

43. Chen, D.; Jiang, M. Strategies for Constructing Polymeric Micelles and Hollow Spheres in Solution via Specific Intermolecular Interactions. Acc. Chem. Res. 2005, 38, 494-502. [CrossRef] [PubMed]

44. Nie, L.; Liu, S.; Shen, W.; Chen, D.; Jiang, M. One-Pot Synthesis of Amphiphilic Polymeric Janus Particles and Their Self-Assembly into Supermicelles with a Narrow Size Distribution. Angew. Chem. Int. Ed. 2007, 46, 6321-6324. [CrossRef] [PubMed]

45. Panganiban, B.; Qiao, B.; Jiang, T.; DelRe, C.; Obadia, M.M.; Nguyen, T.D.; Smith, A.A.A.; Hall, A.; Sit, I.; Crosby, M.G.; et al. Random heteropolymers preserve protein function in foreign environments. Science 2018, 359, 1239-1243. [CrossRef] [PubMed]

46. Page Faulk, W.; Malcolm Taylor, G. Communication to the editors: An immunocolloid method for the electron microscope. Immunochemistry 1971, 8, 1081-1083. [CrossRef]

47. Horisberger, M.; Rosset, J. Colloidal gold, a useful marker for transmission and scanning electron microscopy. J. Histochem. Cytochem. 1977, 25, 295-305. [CrossRef]

48. Kübel, C.; Voigt, A.; Schoenmakers, R.; Otten, M.; Su, D.; Lee, T.-C.; Carlsson, A.; Bradley, J. Recent Advances in Electron Tomography: TEM and HAADF-STEM Tomography for Materials Science and Semiconductor Applications. Microsc. Microanal. 2005, 11, 378-400. [CrossRef]

49. Bals, S.; Van Tendeloo, G.; Kisielowski, C. A New Approach for Electron Tomography: Annular Dark-Field Transmission Electron Microscopy. Adv. Mater. 2006, 18, 892-895. [CrossRef]

50. Morise, H.; Shimomura, O.; Johnson, F.H.; Winant, J. Intermolecular energy transfer in the bioluminescent system of Aequorea. Biochemistry 1974, 13, 2656-2662. [CrossRef]

51. Kutrowska, B.W.; Narczyk, M.; Buszko, A.; Bzowska, A.; Clark, P.L. Folding and unfolding of a non-fluorescent mutant of green fluorescent protein. J. Phys. Condens. Matter Inst. Phys. J. 2007, 28, 285223. [CrossRef] [PubMed] 
52. Markova, S.V.; Burakova, L.P.; Frank, L.A.; Golz, S.; Korostileva, K.A.; Vysotski, E.S. Green-fluorescent protein from the bioluminescent jellyfish Clytia gregaria: cDNA cloning, expression, and characterization of novel recombinant protein. Photochem. Photobiol. Sci. 2010, 9, 757-765. [CrossRef] [PubMed]

53. Zhou, J.; Hu, J.; Li, M.; Wang, W.; Liu, Y.; Winans, R.; Li, T.; Liu, T.; Yin, P. Hydrogen Bonding Directed Co-Assembly of Polyoxometalates and Polymer to Core-Shell Nanoparticles. Mater. Chem. Front. 2018, 2, 2070-2075. [CrossRef]

(C) 2020 by the authors. Licensee MDPI, Basel, Switzerland. This article is an open access article distributed under the terms and conditions of the Creative Commons Attribution (CC BY) license (http://creativecommons.org/licenses/by/4.0/). 